\title{
Theoretical Rethinking Cultural Policy Studies: Governmentality, Politics and Public Sphere
}

\author{
Juan Wang \\ University of Oxford, International Gender Studies Centre, Lady Margaret \\ Hall, UK \\ e-mail: Juanjudy@hotmail.com
}

\begin{abstract}
Cultural policy arrangements are situated in complex discursive contexts where different conflicting social interests, policy objectives and values are important conditions in the everyday life of social actors in the policy field. The dispute on cultural policy studies can also be related to power structure and political and cultural sphere in which cultural policy and activities are exercised. The paper refers back the different concepts within cultural policy discourse, followed by the theoretical reflection on both the Habermasian's and Foucauldian's analytical perspectives of cultural policy studies and aims to explore both critical and practical intellectuality within a cultural policy studies field. This paper sought to broaden the mainstream debate within cultural policy studies.
\end{abstract}

Key words: cultural policy studies, governmentality, public sphere, Habermas, Foucault.

\section{Introduction}

Cultural studies have experienced a significant development in the field of social science and humanities in the past decades, which provided an explanation of different forms of social and political practice within a cultural sphere and a definition of how social structure and cultural power are related to each other through a symbolic repression of a social and cultural system (Hartley, 2003; Grossberg, 2010). Yet, despite theoretical achievement, cultural studies' theoretical and instrumental approach claims to play a crucial role in engaging with cultural issues on the policy agenda, and it is only in recent decades that cultural studies are seen as a meaningful political enterprise.

It is also due to this that cultural studies have often been related to the political economy. For instance, as Hesmondhalgh (2005) states, political economy approaches have more to offer than have cultural economic studies in terms of analysing power relations with regard to cultural production. 
A contemporary cultural study theory together with an understanding of the deep values of culture has become crucial for cultural policy studies; the relation to cultural representation is 'political' because it is bound up with questions of power. For instance, Bennett (1993) argues that textual politics, with which cultural studies has been associated, ignores the institutional dimensions of cultural power. Here Bennett introduces a policy orientation into cultural policy. As cultural policy studies was developed from cultural studies, it will help us to bring a policy analysis to the field of cultural studies and will assist us in understanding how power is exercised within a cultural and political sphere. However, cultural policy embraces the broad field of public processes involved in the governmental intervention in, and support of cultural activity (Cunningham, 1992).

There is no doubt that cultural evaluation and policy-making is a very complex business, and various levels might need to be examined, for instance, the work of the system, channels, specific performance, and different roles in the assessment. Therefore, without the relevant apparatus of cultural analysis, the role of cultural policy will be both unclear and un-manageable. All types of cultural analysis research required to investigate policy will need to be capable of dealing with a much wider set of social problems, such as the issue of social equality and inequality, aesthetics, identity, social inclusion and exclusion, regeneration, marketization and consumption and so on. The complex fusing of cultural analysis and cultural policy can make a key contribution to these debates.

\section{Cultural Policy and Marketization}

Hesmondhalgh (2002) argues that governments and businesses in the Western world responded to the downturn in the 1970 s by starting to move away from the traditional manufacturing industries and towards new sectors in order to maintain profit and productivity levels. Therefore, the cultural industries, as the agents of economic, social, and cultural change, became the key sectors to which the governmental communication policy turned. However, what is the relationship among cultural policy, cultural industry and market mechanism in relation to the issues on individualism and cultural consumption?

For instance, McGuigan (2004:122) argues that "for Adorno and Horkheimer, commodity exchange and serial production signalled the degeneration of culture under monopoly capitalism. The products of the cultural industries were formulaic and repetitive; and they espoused pseudo-individualism". The message of the cultural industry was that everyone could achieve personal happiness through commodity consumption. Whereas today in material production, the mechanism of supply and demand is disintegrating, in the superstructure, it still operates in the rulers' favour. The consumption of culture for most consumers most of the time has nothing to do with public subsidy. The performance of market-oriented cultural industries and mass-popular consumption are the main features of the dominant system (Garnham, 1990). Especially during the 1980s, the combination of cultural populism and 
free market economics appeared in British society when the Thatcher governments transformed Britain from a European social democracy to a free-market economy (Hoggart, 1995). Cultural populism here can be broadly understood as a view that offers a critical perspective on the relationship between culture and the broader society and simply celebrates the postmodern plurality of the market system.

However, the consumers are also workers, and most importantly, citizens. Taking Britain for example, the question that should be asked here is whether ordinary people can achieve their cultural needs when the cultural market has simply followed a policy on privatisation in the capitalist society prevalent in Britain since the 1980s. For instance, in the culture-led strategies employed by urban authorities as production- or consumption-oriented models, a new parlance of 'cultural investment' has become common currency. This is used by those authorities keen to promote themselves as efficient partners for the private sector to encourage capital inflows in the form of public-private partnerships (Bianchini and Parkinson, 1993; Matarasso, 1996). Private partnerships and stakeholders have dominated the cultural market since then, and a more critical public voice seems to have been left behind. Cultural products have simply followed the rules of the market mechanism; a demand not only from individuals, but also from mass consumers' needs for a diverse cultural market is becoming a serious issue. Here my argument is that the needs of citizenship have been displaced by the wants of citizens.

\section{The Nature of Capitalizing on Culture}

Many cultural studies scholars agree with the majority of Marxists in highlighting the debate between social system, mass culture, consumption and capitalist hegemony; for example, Kellner (2006) states, "Cultural studies from the early 1960s to the early 1980s adopted a Marxian approach to the study of culture and cultural politics, one especially influenced by Althusser and Gramsci" (Kellner, 2006:142). Previously, he had commented on the development of cultural studies, arguing that Marxism has historically been central to both its formation and the development of many of its central concepts. This has been significant given the role of the economy more generally in shaping the production, circulation and meanings of culture (Kellner, 2004:1). In his view, Marxian theory is employed to analyse cultural forms in relation to social formation and economic function. Further, the traditions of cultural Marxism are important to the trajectory of cultural studies and to the understanding of its various types and forms in the present age (Kellner, 2004).

The term 'cultural Marxism' is frequently used in discussions regarding culture, politics, ethics, and current affairs. In particular, in the classical period of British cultural studies from the early 1960 s to the early 1980s, many theorists continued to adapt a Marxist approach to the study of culture. Yet, philosophers like Horkheimer and Adorno (1997) argued that to be able to translate Marxism from economic into cultural terms, we need to contradict Marx's own theory on some points. For instance, they argued that culture was not just part of Marx's notion of the 'superstructure' 
of society, but should be understood in terms of changes in the broader capitalist system. In their view, culture became increasingly central to the organisation of capitalism and the extent to which it was converted into an industry, and was increasingly utilised to manipulate mass opinions of loyalty. Culture, then, was both a commodity and an ideology.

On the one hand, British cultural studies have developed a form of post-Marxism concerned with discourse and the new configuration of capitalism and politics that emerged in Western society. On the other hand, as Kellner points out, "British cultural studies concluded that mass culture was playing an important role in integrating the working class into existing capitalist societies and that a new consumer and media culture was forming a new mode of capitalist hegemony" (Kellner, 2003:168). However, what is meant by 'a new mode of capitalist hegemony' within the field of cultural studies? Antonio Gramsci offered an explanation of the theory of hegemony. His model of hegemony and counter-hegemony is based on an understanding of the social and cultural forces of domination and the social forces of resistance and struggle (Gramsci, 1971). He also aimed to explain social transformation and attempted to specify forces of domination and resistance in order to aid the process of political struggle and emancipation from oppression and domination. In Kellner's view, that cultural representations promote racism, sexism, classicism, and other forms of oppression can be analysed through notions of hegemony. If Gramsci's explanation is correct, this kind of new force of cultural capitalism could end up devouring public cultural resources, from classical music to modern arts; when the culture is absorbed into the economic circle, only commercial goods will be left to hold society together.

The critical question in this new age of capitalist society is whether civilization can exist when more and more of our social relationships outside the family become a paid-for experience. Can life experiences take place in one kind of culture form, a certain type of culture that can also be paid for? Can the quality of that experience be measured economically? Has capitalist society actually adopted culture as another form of commodity or commercial product in order to serve the purpose of capitalist hegemony? The capitalist system is based on private ownership and consolidation of the means of production where the production of commodities is guided by the profit motive to satisfy human desires.

Within the socio-historical context in which culture became a commodity, Jameson has developed a particularly influential analysis of our current postmodern condition. According to Jameson (Jameson, 1991), postmodernity has transformed the historical past into a series of emptied-out stylizations that can then be commodified and consumed. Postmodernism is therefore a cultural form which has developed in the wake of the socio-economical order of present day capitalism. Again, postmodernism in Jameson's view is not an all-encompassing trend but rather a cultural dominant that affects all cultural productions. This approach accounts for the existence of other cultural modes of production while still enabling to treatment of our time as postmodern. Other types of art, literature and architecture which are not wholly postmodern are still produced nowadays, but nevertheless postmodernism 
is the field force, the state of culture, through which cultural urges of very different types have to go.

Taking up Jameson's postmodernism as "the cultural logic of late capitalism", Harvey's investigation into post-modernity reveals a problematic construct that though gives voice to otherness, simultaneously ghettoizes them in an "opaque otherness" (Harvey, 1989). Beginnning with the rise of modernism out of Enlightenment thought, Harvey attempts to map the cultural changes that have unfolded from Modernism to post-modernism. He sought to make sense of a particular form of cultural change - the shift to postmodernism in various fields of artistic and philosophical production - and to develop a political economy of culture in the Marxist tradition.

Hall (1996) argues that culture is a mode of ideological reproduction and hegemony in which cultural forms help to shape the modes of thought and behaviour that induce individuals to adapt to the social conditions of capitalist societies (Kellner, 2004). It seems that capitalist society has actually adopted culture as another form of commodity or commercial product in order to serve the purpose of capitalist hegemony, as I argued earlier. In other words, culture here has been treated as a form of commodity; the impact of capitalism on culture has become a serious issue that really stands apart from all of the other economic concerns (Hall, 1980).

Questions of culture and democracy suggest that we need to maintain a relatively non-commodified public sphere to maintain cultural public values. Capitalism is mainly concerned with balance sheets, profit and more instrumental concerns. On the other hand, public values, such as pluralism, service and democracy, are not best served by market principles. Society needs effective policies to provide guidelines for those making decisions and taking actions that affect cultural life rather than simply celebrating the arrival of cultural capitalism. In Rifkin's opinion, cultural capitalism is about the transformation from cultural production to physical production in world commerce and trade (Rifkin, 2000). The debate here is whether cultural policy should really serve this purpose, and should the current cultural policy be allowed simply to follow the rules of the market mechanism and economic regeneration in a capitalist society.

As Rifkin (2000) also highlights, the market has greatly influenced the idea that a common culture is mined for accountable and potential cultural meaning that can be transformed by arts activities into a commodified experience. However, we may have to choose to believe that the market rules our lives; especially in a capitalist society, individuals may have to encounter the market as an ideological framework that has influenced our sense of social reality. The question here is whether cultural policy should pass from politics to economy, if cultural policy has already made this transition, or if these sorts of practice are really different from one another. 


\section{The Notion of Public Sphere and Governmentality Embedded in Culture Policy Studies}

Habermas (1992) highlights how, within the public sphere, discourse becomes democratic by unifying all participants, thus enabling them to overcome their first subjectively biased views in favour of a rationally motivated agreement. Therefore, within this debate, he attempts to introduce democratic judgements that can have a universal application while remaining anchored within the practical realm of discourse among all individuals (Habermas, 1992). Habermas also (1990) posits that the participants in a political sphere share assumptions about communicative practice. These assumptions are produced by an Enlightenment notion of reason that is characteristic of democracy. It is this rationality that makes decisions formulated in discourse binding (Habermas, 1990).

According to Habermas, the idea of the public sphere involves the process of overcoming private thoughts and interests to discover common interests and to reach a societal consensus (Kellner, 2004). Moreover, Habermas's notion of a public sphere also discusses a sphere that will encourage a kind of exercise between the private opinion of all individuals' everyday life in society and the power exercise of the state. Habermas's notion of a 'bourgeois public sphere' means a social sphere where individuals gather together to somehow express their opinions and to act against the unreasonable and domineering form of social power. The democratic public sphere is activated by social movements, pressure groups and critical intellectuals. By addressing questions of key public controversy, these individuals and groups seek to highlight a number of critical problems and questions. Thus, a public sphere can say it is effective according to the extent to which it is able to connect with wider public norms.

The cultural public sphere (McGuigan, 1996) is more like the perpetual interaction between the public interest in culture and the dynamic operations of culture rather than exercising power over others. Missing from Habermas's concerns are the ways in which culture connects with more affective sensibilities that are more often central features of most cultural encounters, from looking at pictures in an art gallery to watching an exciting film on television. While Habermas's explanation of social modernity has its persistent commitment to democracy, it has been influential in the critical analysis within a cultural sphere. Similarly, McGuigan queries whether we should reframe these, as private capital within a public administration has become a key issue to be discussed in the cultural policy field. Therefore, in relation to the above critical debate on cultural policy studies, the argument here is that an idea of cultural policy should be defended in terms of the public values that are necessary to create a democratic society by expanding these dimensions by looking at the affective dimensions of culture.

Foucault's (1984) idea of governmentality is developed in his later work. Here he was concerned to correct the view of power that ignored the possibility of agency. However, Habermas is broadly correct in his criticism that Foucault fails to link the democratic ideal of self-reflection and cultural debate to the potential to reform coercive institutions (Guess, 1981). Hence, governmentality is concerned with not 
only the disciplinary or bio-power of institutions, but also with how power produces knowledge so that individuals can act upon it themselves. Such a view of power does not oppose agency and structure, but looks at how individuals play an active role in their own self government. Hence neo-liberalism or free market capitalism requires not only institutions but the active production of certain identities and subjectivities. In this sense, then, governmentality is concerned with quality of regulation and with how individuals produce themselves in relation to others. Governmentality is concerned not only with institutional design, but also with knowledge and culture.

Since the 1980s, writers in cultural policy studies have used Foucault's writing on governmentality to rethink the relationship between intellectuals in the humanities, governance and liberal states. The recent reconceptualizations of culture have been guided also by Foucault's work on governmentality, discipline, and technologies of the self (Foucault, 1988; 1991). Foucault's notion of 'governmentality' is relatively different from a traditional idea of state power, and it is broadly characterized by its own definition of culture as an administrative measure that is subject to historical investigation (Foucault, 1998). The 're-tooling' of cultural studies along Foucauldian lines has been particularly evident in the new movement of a 'cultural-policy studies' paradigm in Western society (particularly, Britain and Australia) during the late 1980s and 1990s (Craik, 1995).

Bennett (2000) argues for the model of an intellectual as a cultural technician that works within state bureaucracies. Further, beyond Foucault's notion of governmentality as an explanatory matrix of a contemporary cultural policy study, Bennett (1998) challenges the idea that culture is regulated to its own institutional exercises as a form of agency with a modern liberal state under the notion of a rational assumption of agency. Meanwhile, as the chief protagonist of the Foucauldian conceptualization of culture and government, he emphasises that cultural studies needs to accord greater attention to the variable forms of power that characterize particular cultural technologies (Bennett, 1998).

It is worth noting that Bennett focuses on questions about the role of the critical intellectual, the nature of state power and bureaucracy, and the function of culture. It is not difficult to see that his approach retains the Foucauldian notion of governmentality as the explanation of governance as a form of rule (Bennett, 1998). Following the Foucauldian notion of governmentality, Valentine (2002) offers a discussion of the political agency of cultural studies within the contemporary conjuncture. Valentine (2002) argues that the relevance of governance to cultural studies is shown through the argument that the political agency of cultural studies rests on an administrative structure that can no longer be verified empirically or conceptually (Valentine, 2002). However, both Bennett and Valentine have challenged the view that the political agency of culture is expressed through governance from a Foucauldian point of view. 


\section{Rethinking Theoretical Rationale of Culture and its Relevance to Culture Policy Studies}

During the process of producing, individuals can gain valuable aesthetic and emotional experiences that are reproduced through engaging with all kinds of cultural activities. Such a view of culture, then, is critical of attempts to reduce its meanings and practices to the needs of the economy or simply to questions of meaning. Beyond Marxism's notion of culture in economic and social terms, many other theorists and scholars have addressed issues concerning culture, economy and power academically in recent years. Some of them have offered an in-depth critical analysis of cultural policy's historical roots and theoretical function in contemporary society.

How do Habermas's and Foucault's views on culture differ from Marxist theory? How do they criticise Marxist theory? Marxism's account of culture largely agrees that culture is there to make a profit and is being gradually turned into a commodity. Habermas's views, to some extent, belong partly to that tradition; he is also critical of the Marxist tradition, in particular, of Marxist theory on communication. According to Habermas (1996), Marx tries to put together two different understandings of communication. Marxism, on the whole, confuses communication that aims to manipulate and control with communication that also aims at emancipation and reflection. This conclusion is evident in the idea of the false consciousness that fails to recognise members of subordinate classes and groups as equal partners in dialogue and discussion. Marxism, then, in this sense, has historically failed to develop a theory of democracy.

For instance, Stevenson (2002) outlines Habermas's theory in the following way:

For Habermas, the fact that we are language users means that we are communicatively able to reach an understanding of one another. Habermas argues that in every act of speech we are capable of immanently raising three validity claims in connection with what is said. These three validity claims, he adds, constitute a background consensus of normal everyday language in Western society. The three claims-that are used by agents to test the validity of speech could be characterised as propositional truth claims, normative claims related to appropriateness, and the claims connected to sincerity (2002:52).

Yet, Habermas does appreciate some of Marx's theory; his earlier involvement with the Frankfurt school demonstrates this (Eriken and Weigard, 2003). Habermas, for example, values the way in which Marx tries to develop a genuinely cultural theory of society aiming at human emancipation. In Habermas's view, all citizens need a place that is not fully dominated by capitalism; this place should be able to encourage the public to have a kind of critical reflection. Eriken and Weigard (2003) reinterpret Habermas's point in the following way:

Habermas's break with early critical theory is expressed among other things in his wish to revise Marx's old substructure-superstructure model completely, and assign independent meaning to 'superstructure phenomena' such as argument, norms and scientific truths (Eriken and Weigard, 2003:5). 
By debating Marx's ideology of a social system, Habermas is trying to bring together the idea of traditional and liberal freedoms and critical ideas from Marxism. He thinks that Marxist theory has not taken liberalism or liberal ideas seriously enough. For instance, Habermas's interrogation of this debate has important points of reference; he emphasises that "it should be clear that the democratic constitutional state on the one hand requires, in a functional sense, civic virtue and a population that values freedom" (Habermas, 1996:130). On the other hand, Foucault criticises Marxist theory because it considers that society is organised on a single fault line (that is, the struggle between capital and labour); this is the most significant struggle and it has been going on for a long time.

According to the Marxist understanding of power, there is no alternative to an economic analysis of power. Yet, as we shall see, a Foucauldian understanding of power explicitly rejects the idea (central to Marxism) that the class struggle is essential for a more multi-dimensional view of power (Smart, 1985). Here power is dispersed and multiple rather than simply contained in the economic sphere. As we shall see, these critical questions have implications for the ways in which we understand wider questions of culture and policy.

\section{Conclusion}

Cultural policy studies are often generated from a cultural study, and the theoretical transformation from one to the other does not always provide the necessary expertise. Thus, it is very difficult to understand how cultural studies might offer unbiased expertise when one considers the kinds of cases that critical cultural policy studies characteristically addresses. For instance, certain important concepts, such as the locality, which has been discussed frequently, have been partially forgotten in cultural policy. Individual intellectuals who are trained in cultural studies might have a productive role to play in answering these questions theoretically, practically and philosophically. However, these questions need to be discussed not only by experts, but also by the relevant interested parties, both democratically and politically. As an academic discipline, it seems that cultural policy studies itself could not represent such an interest, and the relevant policy advice could not offer the truthful answers that need to be applied in a wide political sphere.

Regarding the issue from a policy-oriented perspective in cultural studies, it can be seen that cultural policy is undergoing a partial shift from the attention paid to cultural texts to the condition of culture. In a more general sense, cultural policy has a close affinity with the political economy perspective on communications and culture. Cultural policy (McGuigan, 2003) is principally about the material and the discursive determinations in the time and the space of cultural production and consumption. The study of cultural policy does not deny the importance of criticism and textual interpretation, but rather puts issues concerning how texts are made and circulated socially into the foreground. Fundamental to the position on cultural policy is the normative view that, in a democratic society, the public should influence the condition of culture due to their persistence and their potential for change. 
This is where a Habermasian view differs most sharply from a Foucauldian view. McGuigan (2016) argues that a Foucauldian might typically regard such thinking as rooted in an Enlightenment rationality and humanism, although a Habermasian perspective might be just as suspicious of Foucauldian claims concerning democracy and public accountability. The literature on cultural policy offers an account of cultural practices that should be productively rethought as normalizing apparatuses central to both the conceptualization and operationalization of modern democratic processes. Of course, Bennett's $(1999,2010)$ conceptualization of culture as a set of practices integral to 'governing at a distance' has usefully directed attention towards the historical inscription of conceptions of culture in a set of practices deployed as part of the political technologies concerned with the limits of state power. The issues in relation to how we use culture as a set of practices for social management have been rethought critically in his writing.

The Foucauldian perspective informs a definition of culture that is closely linked to a particular understanding of policy. While the cultural policy studies has been subject to critical discussions most of the writing is centred on the relationships between culture and policy in the formation and continuing vibrancy of cultural studies. What really emerges from those critical commentaries is that there is a sharper distinction between the analysis of the culture-policy nexus on the one hand, and engaging in the practice of policy-making on the other.

The lack of critical discussion within the cultural-policy paradigm is indicated by the ritual invocation of Foucault's authority from Foucauldian works. Less attention has been paid to the conceptual implications of the contemporary spatial restructuring of cultural practices for the general applicability to all cultural technologies of Foucault's 'diagrammatic' conception of disciplinary power. As part of the broader literature on governmentality, the reconceptualization of culture in relation to the practices of the government and the management of conduct are underwritten by an understanding of disciplinary power. From a Habermasian point of view, the fundamental position on cultural policy is underpinned by an account of a democratic society; here, the public should decisively influence the condition of culture. Culture in this respect should promote critical thinking, civic value and participation in the dominant institutions in society. The crisis of culture from a democratic perspective emerges when the market displaces public values. The effect of more concern is not to discount any of these aspects, but to broaden more critically the scope of what we might understand as falling under the rubric of cultural policy studies. However, the debate inevitably remains. 


\section{References}

1. Adorno, T. W. and Horkheimer, M. (1997). Dialectic of Enlightenment. London: Verso.

2. Bennett, T. (1993). Putting Policy into Cultural Studies, in: During, S. (Ed.). Cultural Studies. London: Routledge.

3. Bennett, T. (1997). Speaking to the eyes: museums, legibility and the social order, in: Macdonald, S. (Ed.). Politics of Display: Science as Culture. London: Routledge.

4. Bennett, T. (1998). Culture: A Reformer's Science. London: Sage.

5. Bennett, T. (2000). Intellectuals, culture, policy: the technical, the practical and the critical. Pavis Papers in Social and Cultural Research, no. 2. Milton Keynes: Open University.

6. Bennett, T. (2010). 'Culture Studies and the Culture Complex', in: Hall, J. R. et al. (Eds.). Culture: A Sociological Handbook. London \& New York: Routledge.

7. Bennett, T.; Savage, M.; Silva, E.; Warde, A.; Gayo-Cal, M.; Wright, D. (2009). Culture, Class, Distinction. London \& New York: Routledge.

8. Bianchini, F. and Parkinson, M. (1993). Cultural Policy and Urban Regeneration: the West European Experience. Manchester: Manchester University Press.

9. Cunningham, S. (1992). The cultural-policy debate revisited. Meanjin, 51 (3): 533-543.

10. Craik, J. (1995). Mapping the links between cultural studies and cultural policy. Southern Review, 28 (2): 190-207.

11. Eriksen, E. O. and Weigard, J. (2003). Understanding Habermas: Communicative Action and Deliberate Democracy. London: Continuum.

12. Foucault, M. (1984). The Care of the Self: History of Sexuality. London: Allen Lane.

13. Foucault, M. (1988). Politics, Philosophy, Culture, Interviews and Other Writings 1977-1984. Kritzman, L. (Ed.). London: Routledge.

14. Foucault, M. (1991). Remarks on Marx. Goldstein, J. and Cascaito, J. (trans). New York: Semiotext(e).

15. Foucault, M. (1998). Athletics, Methods, and Epistemology: Essential Works of Foucault 1954-1984, Vol. 2. Foubion, J. D. (Ed.). New York: New Press.

16. Garnham, N. (1990). Capitalism and Communication-Global Culture and Economics of Information. London: Sage.

17. Gramsci, A. (1971). Selections from the Prison Notebooks .New York: International Publishers.

18. Guess, R. (1981). The Idea of Critical Theory. Cambridge: Cambridge University Press.

19. Grossberg, L. (2010). Cultural Studies in the Future Tense. Durham. NC: Duke University Press.

20. Habermas, J. (1989). The Structural Transformation of the Public Sphere-an Enquiry into a Category of Bourgeois Society. Cambridge: Polity Press.

21. Habermas, J. (1990). Moral Consciousness and Communication Action. Cambridge: Polity Press.

22. Habermas, J. (1996[1992]). Between Facts and Norms. Cambridge, Mass: MIT Press. 
23. Hall, S. (1980). Cultural Studies and the centre: some problematic and problems, in: Hall, S.; Hobson, D.; Love, A.; Willis, P. (Eds.). Culture, Media, Language. London: Hutchinson.

24. Hartley, J. (2003). A Short History of Cultural Studies. London: Sage.

25. Harvey, D. (1989). The Condition of Postmodernity: An Enquiry into the Origins of Cultural Change. Oxford, UK: Blackwell.

26. Hoggart, R. (1995). The Live we Live now. London: Chatto and Windus.

27. Jameson, F. (1991). Postmodernism, or, The cultural logic of late capitalism. Durham: Duke University Press.

28. Kellner, D. (2003). Critical theory, in: Curren, R. (Ed.). A Companion to the Philosophy of Education. London: Blackwell.

29. Kellner, D. (2006). Cultural Studies and Philosophy: an Intervention, in: Miller, T. (Ed.). A Companion to Cultural Studies. London: Blackwell.

30. Lemke, T. (2002). Foucault, Governmentality, and Critique. Rethinking Marxism, 14 (3): 49-64.

31. Matarasso, F. (1996). The Art of Regeneration: Urban Renewal through Cultural Activity. Stroud: Comedia.

32. McGuigan, J. (1996). Culture and the Public Sphere. London: Routledge.

33. McGuigan, J. (2003). Cultural policy studies, in: Lewis, J. and Miller, T. (Eds.). Critical Cultural Policy Studies: A Reader. London: Blackwell.

34. McGuigan, J. (2016). Neoliberal Culture. Palgrave Macmillan, UK.

35. Rifkin, J. (2000). The Age of Access. New York: Tarcher/Putnam.

36. Smart, B. (1985). Michel Foucault. London: Routledge.

37. Stevenson, N. (2002). Understanding Media Cultures: Social Theory and Mass Communication. London: Sage.

38. Valentine, J. (2002). Governance and cultural authority. Cultural Values, 6 (1): 47-62. 
Pregledni rad

Juan Wang

Sveučilište Oxford, Internacionalni centar za rodne studije, Lady Margaret Hall, Velika Britanija e-mail: Juanjudy@hotmail.com

Teoretsko preispitivanje studija kulturne politike: vladavina, politika i javna sfera

\section{Sažetak}

Kulturna politika dio je složenog diskurzivnog konteksta u kome raznoliki konfliktni društveni interesi, ciljevi i vrijednosti predstavljaju važne uvjete za svakodnevno djelovanje društvenih aktera kulturne politike. Rasprava o kulturnoj politici također je vezana uz strukturu moći te politički i kulturni prostor, gdje se ona i njezine aktivnosti odvijaju. Rad se referira na različite koncepte diskursa o kulturnoj politici nakon čega slijedi teoretsko promišljanje analitičkih osvrta Habermasa i Foucaulta na studije kulturne politike. Također nastojimo osvijetliti s kritičke, ali i praktične točke gledišta to kompleksno područje. Ovaj rad želi proširiti raspravu o kulturnoj politici i njenim dosezima.

Ključne riječi: studiji kulturne politike, koncept kulturne politike, javna sfera, Habermas, Foucault. 